\title{
Editorial
}

O presente Cadernos EBAPE.BR procura dar continuidade àquilo que foi proposto no vol. 1, n. 1 de 2003: ser um periódico a contrapelo da hegemonia funcionalista predominante em revistas dedicadas ao management. Nenhuma novidade uma vez que aqui e ali, no Brasil e alhures, são publicados artigos que procuram afugentar a literatura dominante no ensino da Administração. Desse modo, o número temático que ora divulgamos, Management Industry, estruturado na gestão anterior pela ex-editora Profa. Ana Lucia Guedes, tem por intenção estimular o debate na medida em que a cultura gerencial contemporânea, referenciada pelas necessidades do mercado, e apenas deste, tem descuidado das contradições que ele gera no fluir histórico das sociedades. Fenômeno que não se restringe às práticas gerenciais, também no processo ensino-aprendizagem o determinismo de mercado foi muito bem expresso por Guerreiro Ramos no seu inspirador livro A nova ciência das organizações: uma reconceituação da riqueza das nações (Rio de Janeiro, Editora da Fundação Getulio Vargas, 1981).

A ingenuidade, à qual nos alerta Guerreiro Ramos logo no início do seu livro, ainda parece fazer parte de um pensamento único e preponderante: produzir textos e treinar indivíduos (a expressão "treinar indivíduos" é proposital), que se alinhem exclusivamente ao desempenho no e do mercado e às necessidades do bem viver do homem em sociedade. Não por acaso, expressões como "governança", "responsabilidade social", "sustentabilidade", "decrescimento", "logística reversa" e outros assemelhados são incorporados ao vocabulário da cultura do management; consequentemente nos cursos de Administração, com o objetivo de minimizar os efeitos (ou mal feitos?) provocados por processos de tomada de decisão alheios ao bem comum. Assim, nos artigos ora incorporados ao presente número do Cadernos EBAPE.BR,busca-se dar conta de uma linha editorial não agendada, tão somente, pelo utilitarismo funcionalista dominante, mas pela possibilidade de pôr em pauta interpretações não estritamente alinhadas com a racionalidade instrumental.

A edição deste número especial contou com a colaboração dos seguintes editores convidados: Alessandra de Sá Mello da Costa (PUC-RJ); Denise Franca Barros (UNIGRANRIO); e Luiz Alex Silva Saravia (UFMG). São os seguintes os artigos a compor esta edição:

Uma narrativa sobre os cursos superiores em Administração da FACE/UFMG: dos primeiros anos à sua unificação em 1968

Amon Barros

MBAs: cinco discursos em busca de uma nova narrativa

Thomaz Wood Jr; Julia Fernandes Personini Cruz

Impactos da Globalização no Processo de Internacionalização dos Programas de Educação em Gestão

Ana Christina Celano; Ana Lucia Guedes

Hipergeneralizações: organizações são quase qualquer coisa em bestsellers de introdução à Administração

Guilherme Lima Moura

Sucesso, mídia de negócios e a cultura do management no Brasil

Cristiana Trindade Ituassu; Maria José Tonelli

Cad. EBAPE.BR, v. 12, no 1, editorial, Rio de Janeiro, Jan./Mar. 2014. 
Carreira, família e a dialógica do assujeitamento: o discurso vigente em uma revista popular de negócios

Andrea Poleto Oltramari; Bibiana de Paula Friderichs; Denize Grzybovski

\section{Cultura Organizacional e Avanço do Management na Marina do Brasil}

Maria de Fátima Bandeira dos Santos; Ana Carolina Pimentel Duarte da Fonseca; Fernanda Filgueiras Sauerbronn

A cultura de belezas americanas: gestão de pessoas, discurso e sujeito

Fabio Bittencourt Meira; Mônica Birchler Vanzella Meira

Investidas do management no campo da cultura em Pernambuco: o caso dos produtores culturais Elisabeth Cavalcante dos Santos; Debora Coutinho Paschoal Dourado

Boa leitura, e esperamos mais contribuições ao debate. Lembrando aos leitores que, na sequência deste ano de 2014, será publicado o número temático "Estudos Organizacionais e Filosofia" onde pretendemos dar continuidade ao desafio proposto desde a criação do Cadernos EBAPE.BR em 2003.

Fernando G. Tenório

Editor 